\title{
Reaction of a Bean Germplasm Collection Against Five Races of Colletotrichum lindemuthianum Identified in Northern Spain and Implications for Breeding
}

\author{
Juan José Ferreira, Ana Campa, and Elena Pérez-Vega, Area de Cultivos Hortofrutícolas y Forestales, Servicio \\ Regional de Investigación y Desarrollo Agroalimentario (SERIDA), 33300, Villaviciosa, Asturias, Spain; and \\ Ramón Giraldez, Department of Biología Funcional, University of Oviedo, 33006 Oviedo, Asturias, Spain
}

\begin{abstract}
Ferreira, J. J., Campa, A., Pérez-Vega, E., and Giraldez, R. 2008. Reaction of a bean germplasm collection against five races of Colletotrichum lindemuthianum identified in northern Spain and implications for breeding. Plant Dis. 92:705-708.

Anthracnose, caused by Colletotrichum lindemuthianum, is one of the most serious diseases of common bean (Phaseolus vulgaris). The pathogenic variability of this fungus in northern Spain and the response of a bean germplasm collection maintained at Servicio Regional de Investigación y Desarrollo Agroalimentario (Villaviciosa, Asturias, Spain) were screened in order to identify potential resistance sources. Races $3,6,19,38$, and 102 were identified from 55 isolates colleted in this area, race 38 being the most common one. In all, 246 landraces and 42 lines derived from breeding programs were evaluated in search of resistant lines. No local accession showed adequate resistance to the five races. However, three local accessions were resistant to four races and presented intermediate or mixed reactions against the fifth one: accession V225, with a large great northern seed phenotype $\left(\mathrm{R}^{3} \mathrm{R}^{6} \mathrm{I}^{38} \mathrm{R}^{102} \mathrm{R}^{19}\right)$; accession $\mathrm{V} 369$, with a great northern seed phenotype $\left(R^{3} R^{6} R^{38} R^{102} R / S^{19}\right)$; and accession $V 309$, with a navy seed phenotype $\left(R^{3} R^{6} R^{38} R / S^{102} R^{19}\right)$. The results revealed a wide variation in the resistance spectra or resistance combinations, although not all the possible resistance spectra were present in the evaluated accessions. Among the breeding lines, nine materials were resistant to five races and three lines (A252, A321, and A493) were selected as resistance sources to transfer genetic resistance to Andecha bean cultivar. The results indicated that lines A252 and A321 have two dominant and independent genes involved in the resistance to race 38 whereas line A493 has a single locus.
\end{abstract}

Additional keywords: evaluation

Anthracnose, caused by Colletotrichum lindemuthianum (Sacc. \& Magnus) Briosi \& Cavara, is one of the most devastating diseases of common bean (Phaseolus vulgaris L.). The disease is common in mild and wet areas like northern Spain, where it causes severe economic losses in the locally grown fabada market class, the most widely planted in this area. Anthracnose control is difficult on cultivars of this market class because of their indeterminate climbing growth habit and the efficient transmission of pathogen by means of seed or plant debris. Incorporation of genetic resistance to this market class should be the most economical and effective method to control the disease.

With few exceptions (4), the bean hostC. lindemuthianum interaction generally shows qualitative inheritance in which each resistance gene protects against spe-

Corresponding author: J. J. Ferreira

E-mail: jjferreira@ serida.org

Accepted for publication 31 October 2007.

doi:10.1094/PDIS-92-5-0705

This article is in the public domain and not copyrightable. It may be freely reprinted with customary crediting of the source. The American Phytopathological Society, 2008. cific races of $C$. lindemuthianum. So far, 11 genes conferring resistance to specific races have been described in common bean. Molecular markers linked to the majority of these genes provide a tool for the marker-assisted selection and gene pyramiding (7). Most of these resistance genes are present in the set of 12 differential cultivars adopted to characterize the pathogenic diversity of this fungus (13). Using this set, numerous races have been described throughout the world $(1,2,10,19)$. However, there is little information on the pathogenic diversity for this fungus in northern Spain (10).

The wide pathogenic variability of this pathogen and the emergence of new races complicate the development of resistant cultivars. Information about the local pathogenic diversity is essential before starting a breeding program focused on the protection of a local cultivar against this fungus. Moreover, there is a need to identify bean sources with resistance to multiple races of the pathogen for the long-term success of the breeding program. Local germplasm could provide useful sources of resistance that are adapted to specific environments $(14,18)$. This article reports the pathogenic variability found in anthracnose isolates collected in northern Spain and the reaction of local common bean accessions and elite breeding lines to them. In addition, inheritance of the resistance against one race is studied.

\section{MATERIALS AND METHODS}

Plant material. In all, 288 bean accessions maintained at the Servicio Regional de Investigación y Desarrollo Agroalimentario collection (Villaviciosa, Asturias, Spain) were evaluated for their response to anthracnose races identified in northern Spain. These accessions included 246 landraces that, according to the classification proposed by Santalla et al. (16), belong to the most frequent bean market classes harvested in northern Spain, including fabada, large great northern, white kidney, and canellini. Andecha and Cimera bean cultivars obtained through an individual selection program and with a fabada seed phenotype also were included in this set.

The remaining 42 accessions were breeding lines obtained from different programs: A252, A321, A43, A475, A483, A493, A797, ABA36, ABA58, ABA71, Amanda, ARA17, Araucano INIA 85, BAT93, Blanco Español, Blanco Lara, BRB130, BRB173, BRB19, BRB26, BRB57, BRB85, Canadian Wonder, Canario 107, Cardinal, Catrachita, Chase, Don Timoteo, Double White, IVT7214, JaloEEP558, Monroe, Pinto 114, PVA800A, Red Mexican U13, Sanilac, SEL1308, SEL1360, Tendergreen, UI 906, WAF9, and XAN265. Breeding lines originally were supplied by S. P. Singh (Kimberly Research and Extension, University of Idaho) and by J. D. Kelly (Department of Crop and Soil Science, Michigan State University).

Resistance test. The inoculations were carried out according to Pastor Corrales et al. (14). To produce inoculum, the fungus was grown on potato dextrose agar at $22^{\circ} \mathrm{C}$ for 7 days in darkness. Conidia were washed from the medium and suspended in sterile distilled water. The spore concentration was adjusted to $1.2 \times 10^{6}$ spores $/ \mathrm{ml}$ with the help of a hemacytometer. The inoculations were carried out in seedlings with fully expanded primary leaves. The inoculated seedlings were maintained at moderate temperature $\left(20\right.$ to $\left.24^{\circ} \mathrm{C}\right)$ in a humidity chamber for about 7 days. Disease reactions were assessed using a 1-to-9 severity scale considering the percentage of the seedling with lesions where $1=$ no visible symptoms and $9=$ severely dis- 
eased or dead plant $(2,23)$. Plants with no visible symptoms or very small lesions were registered as resistant (severity scale 1 to 3 ). Seedlings with numerous small lesions on the leaves or stems were recorded as intermediate (severity scale 4 to 6). Seedlings with multiple lesions on the leaves and stems or dead plants were registered as susceptible (severity scale 7 to 9 ).

Race characterization. Samples of $C$. lindemuthianum were collected in different locations in northern Spain (Asturias, Lugo, Coruña, and Cantabria) during the period 1995 to 2000 . Isolations were made according to Sicard et al. (19) from seed or pods of naturally infected bean plants. A monosporic culture was obtained from each isolate and kept in a stock of funguscolonized filter paper at $-20^{\circ} \mathrm{C}$ (14). Monosporic cultures were characterized using the standard set of 12 differential cultivars (13). Ten seedlings per differential cultivar were inoculated for the race characterization. Pathogenic variants were named based on a numerical system where the name for a race was the sum of the binary value assigned to the susceptible differential cultivars (13). The identity of each pathogenic variant was confirmed in several evaluations.

Germplasm evaluation. A monosporic culture of each race was used in the germplasm evaluation. At least 20 seeds per accession were planted in peat in plastic trays and maintained at 20 to $24^{\circ} \mathrm{C}$ in a greenhouse. In each inoculation, the set of 12 differential cultivars was incorporated as resistant or susceptible control scale for the evaluation. After 7 to 9 days, seedlings with fully expanded primary leaves were spray inoculated with the aqueous conidial suspensions. In order to confirm the resistance spectra, a second evaluation was carried out on local accessions that had resistance to at least three races and in all the breeding lines.

Inheritance of resistance. Three resistant lines, A252, A321, and A493, were selected as potential resistance sources against local races. In order to know the nature of resistance in the lines selected, three F2 populations were developed from crosses between these resistant lines and the susceptible cv. Andecha. The inheritance of resistance against one of the anthracnose races was investigated by means of the reaction of $\mathrm{F} 2$ and $\mathrm{F} 3$ plants. A minimum of $16 \mathrm{~F} 3$ seedlings derived from each F2 plant were evaluated in order to classify F3 families as having all resistant individuals (R), resistant and susceptible individuals $(\mathrm{R} / \mathrm{S})$, or all susceptible individuals (S). Simple disease inheritance was confirmed by using a $\chi^{2}$ test.

\section{RESULTS}

Race characterization. In the period 1995 to 2000, 55 monosporic cultures derived from isolates collected in 36 locations in northern Spain were obtained. The reaction of differential bean cultivars revealed the existence of five pathogenic variants (Table 1): races 3, 6, 19, 38, and 102. The most common variant, race 38 , was isolated from market classes with white and large seed (fabada, white kidney, canellini, and large great northern) whereas race 6 was isolated from fabada market class. Races 3 and 19 were isolated from snap bean cultivars and race 102 was isolated from a landrace included in a black turtle market class. Races 6 and 38 caused more rapid and severe symptoms on the susceptible differential cultivars. Isolates classified as race 19 caused few and very small lesions on TO and TU differential cultivars; sporulation was never observed on these lesions.

Germplasm evaluation. The responses of local landrace germplasm to the five races identified in the present work are summarized in Table 2. Four types of reactions were distinguished in the accessions: resistant $(\mathrm{R})$, in which all the plants evalu-

Table 2. Reaction of a bean germplasm collection, landraces and breeding lines, evaluated against five races of Colletotrichum lindemuthianum isolated from Phaseolus vulgaris in the northern Spain

\begin{tabular}{|c|c|c|c|c|c|c|c|}
\hline \multirow[b]{2}{*}{ Race } & \multirow[b]{2}{*}{ Accession } & \multicolumn{4}{|c|}{ Types of reactions ${ }^{a}$} & \multirow[b]{2}{*}{ Total } & \multirow[b]{2}{*}{ Susceptible $(\%)^{\mathrm{t}}$} \\
\hline & & $\mathbf{R}$ & $\mathbf{S}$ & $\mathbf{R} / \mathbf{S}$ & $\mathbf{I}$ & & \\
\hline \multirow[t]{2}{*}{3} & Landrace & 78 & 144 & 11 & 13 & 246 & 58.5 \\
\hline & Breeding lines & 16 & 25 & 0 & 1 & 42 & 59.5 \\
\hline \multirow[t]{2}{*}{6} & Landrace & 24 & 212 & 3 & 7 & 246 & 86.2 \\
\hline & Breeding lines & 17 & 23 & 0 & 2 & 42 & 54.8 \\
\hline \multirow[t]{2}{*}{38} & Landrace & 39 & 198 & 5 & 4 & 246 & 80.5 \\
\hline & Breeding lines & 21 & 18 & 0 & 3 & 42 & 42.9 \\
\hline \multirow[t]{2}{*}{102} & Landrace & 52 & 167 & 9 & 18 & 246 & 67.9 \\
\hline & Breeding lines & 27 & 14 & 0 & 1 & 42 & 33.3 \\
\hline \multirow[t]{2}{*}{19} & Landrace & 82 & 147 & 10 & 7 & 246 & 59.8 \\
\hline & Breeding lines & 19 & 21 & 2 & 0 & 42 & 50 \\
\hline
\end{tabular}

${ }^{a} \mathrm{R}=$ resistant, $\mathrm{S}=$ susceptible, $\mathrm{I}=$ intermediate reaction, and $\mathrm{R} / \mathrm{S}=$ plants resistant and susceptible.

b Percentage of susceptible accessions. ated were found to be resistant; susceptible $(\mathrm{S})$, in which all plants showed severe disease symptoms; accessions with intermediate reaction (I), in which all plants were moderately susceptible; and accessions containing resistant and susceptible plants $(\mathrm{R} / \mathrm{S})$. Clear evidence of mixed reactions for the response to some strains was detected in a total of 40 local accessions, including the majority of the market classes. This suggests that there were at least two genotypes present in these accessions. Presence of resistant and susceptible materials within the same accession provides the opportunity to select resistant materials. In all, 41 accessions, including 10 market classes (azufrado, bayo gordon, black turtle, brown garbanzo, canellini, fabada, great northern, large great northern, marrow, and navy) were resistant to at least three races in two independent evaluations. Race 6 was virulent on most the landraces ( $80 \%$ of accessions were susceptible) whereas race 3 was virulent on a majority of the breeding lines. Races 6 and 38 were particularly aggressive on fabada accessions, causing severe symptoms and death of the seedlings in a few days. Nine accessions, including market classes navy (three accessions), great northern (one accession), and black turtle (five accessions) were resistant to races 6 and 38 .

No local accession showed complete resistance to all five races identified in this study. However, three accessions were resistant to four races and presented intermediate or mixed reactions against the fifth one: accession V225, with a "large

Table 1. Characterization of isolates of Colletotrichum lindemuthianum collected from Phaseolus vulgaris growing in northern Spain

\begin{tabular}{|c|c|c|c|c|c|c|c|c|c|c|c|c|c|}
\hline \multirow[b]{2}{*}{ Race } & \multicolumn{12}{|c|}{ Differential cultivars $^{\mathbf{a}}$} & \multirow[b]{2}{*}{ Number of isolates } \\
\hline & $\mathbf{A}$ & B & $\mathbf{C}$ & D & $\mathbf{E}$ & $\mathbf{F}$ & G & $\mathbf{H}$ & $\mathbf{I}$ & $\mathbf{J}$ & $\mathbf{K}$ & $\mathbf{L}$ & \\
\hline 3 & $\mathrm{~S}$ & $\mathrm{~S}$ & $\mathrm{R}$ & $\mathrm{R}$ & $\mathrm{R}$ & $\mathrm{R}$ & $\mathrm{R}$ & $\mathrm{R}$ & $\mathrm{R}$ & $\mathrm{R}$ & $\mathrm{R}$ & $\mathrm{R}$ & 1 \\
\hline 6 & $\mathrm{R}$ & $\mathrm{S}$ & $S$ & $\mathrm{R}$ & $\mathrm{R}$ & $\mathrm{R}$ & $\mathrm{R}$ & $\mathrm{R}$ & $\mathrm{R}$ & $\mathrm{R}$ & $\mathrm{R}$ & $\mathrm{R}$ & 2 \\
\hline 38 & S & S & $\mathrm{R}$ & $\mathrm{R}$ & $\mathrm{S}$ & $\mathrm{R}$ & $\mathrm{R}$ & $\mathrm{R}$ & $\mathrm{R}$ & $\mathrm{R}$ & $\mathrm{R}$ & $\mathrm{R}$ & 46 \\
\hline 102 & $\mathrm{~S}$ & $\mathrm{~S}$ & $\mathrm{R}$ & $\mathrm{R}$ & $\mathrm{S}$ & $\mathrm{S}$ & $\mathrm{R}$ & $\mathrm{R}$ & $\mathrm{R}$ & $\mathrm{R}$ & $\mathrm{R}$ & $\mathrm{R}$ & 4 \\
\hline $19^{\mathrm{b}}$ & $\mathrm{S}$ & $\mathrm{S}$ & $\mathrm{R}$ & $\mathrm{R}$ & $\mathrm{S}$ & $\mathrm{R}$ & $\mathrm{R}$ & $\mathrm{R}$ & $\mathrm{R}$ & $\mathrm{R}$ & $\mathrm{R}$ & $\mathrm{R}$ & 2 \\
\hline
\end{tabular}

${ }^{a}$ Letters A to $\mathrm{L}$ designate differential cultivars used to type races of $C$. lindemuthianum. Their identification and their respective binary value (in parentheses) are A = Michelite (1), B = Michigan Dark Red Kidney (2), C = Perry Marrow (4), D = Cornell 49242 (8), E = Widusa (16), F = Kaboon (32), G = Mexique 222 (64), $\mathrm{H}=\mathrm{PI} 207262$ (128), I = TO (256), J = TU (512), $\mathrm{K}=\mathrm{AB} 136$ (1,024), and L = G2333 (2,048). $\mathrm{R}=$ resistant and $\mathrm{S}=$ susceptible.

${ }^{\mathrm{b}}$ Isolates classified as race 19 caused few and very small lesions on TO and TU differential cultivars; sporulation was never observed on these lesions. 
great northern" seed type $\left(\mathrm{R}^{3} \mathrm{R}^{6} \mathrm{I}^{38} \mathrm{R}^{102} \mathrm{R}^{19}\right)$; accession V369, with a "great northern" seed type $\left(R^{3} R^{6} R^{38} R^{102} R / S^{19}\right)$; and accession V309, with a "navy" seed phenotype $\left(R^{3} R^{6} R^{38} R / S^{102} R^{19}\right)$. Because of the limited number of resistance sources to the five races identified in the evaluation of local germplasm, the response of a set of lines derived from breeding programs was analyzed (Table 3). Seven breeding lines (A43, A252, A321, A493, BAT 93, SEL1360, and SEL1308) and cultivars Catrachita and Amanda were resistant to five strains $\left(R^{3} R^{6} R^{38} R^{102} R^{19}\right)$.

The independent evaluation of each race showed a relatively high level of polymorphism in the resistance spectrum. Considering together the reaction against the five races, and only two reaction types per race (resistant or susceptible), 32 different resistant-susceptible combinations would be possible with five races. In the present work, 19 different combinations were identified in the local accessions evaluated, the most common ones being: $S^{3} S^{6} S^{38} S^{102} S^{19}$ (78 accessions), $R^{3} S^{6} S^{38} S^{102} R^{19}$ (23 accessions), $S^{3} S^{6} S^{38} R^{102} S^{19}$ (13 accessions), $R^{3} S^{6} S^{38}$ $R^{102} R^{19}$ (12 accessions), and $S^{3} S^{6} R^{38} S^{102} S^{19}$ (10 accessions).

Inheritance of resistance. In order to test the nature of resistance in lines A252, A321, and A493, the lines were individually crossed with cv. Andecha
$\left(R^{3} S^{6} S^{38} R^{102} R^{19}\right)$ and segregation for resistance to race 38 was evaluated on F2 plants. The results established that resistance in the three lines was qualitative because only two types of reaction, resistant or susceptible, were identified (Table 4). The segregation obtained in the F2 populations involving lines A321 and A252 supported an expected 15R:1S ratio $\left(\chi^{2}=0.00, P>0.05\right)$, indicating that resistance is controlled by two dominant loci. The segregation patterns observed in F2 populations derived from the Andecha/A493 cross supported an expected 3R:1S ratio $\left(\chi^{2}=0.22, P>0.05\right)$, indicating that A493 carries a single dominant gene conditioning resistance to race 38 . These results obtained in F2 populations were confirmed by the analysis of F3 families. In the case of segregations involving lines A321 and A252, the results showed a good fit to the expected ratio for two independent dominant genes (7R:8R/S:1S). In the case of the F3 families derived from Andecha/A493, the observed segregation showed a good fit to the expected ratio for one dominant gene (1R:2R/S:1S).

\section{DISCUSSION}

Pathogenic diversity analysis revealed the occurrence of five races in northern Spain. Races 3, 6, 38, and 102 have been identified previously in other countries of
Europe and America $(1,2,9,10,14,19)$. The extensive distribution of some races could be explained by the seedborne nature of this pathogen (22) and the intensive exchange of noncertified anthracnose-free seed among bean-producing regions.

According to morphological traits, phaseolin seed protein, and molecular markers, two principal gene pools have been described in common bean: Middle American and Andean gene pools $(6,20,21)$. Most landraces grown in the Iberian Peninsula are connected with the Andean gene pool $(5,17)$. The five races identified in this work preferentially attack the Andean differential cultivars M.D.R.K., Perry Marrow, Kaboon, or Widusa (Table 1). Other works also found that races isolated from Andean cultivars showed a broader virulence on germplasm of this gene pool and a reduced virulence on Middle America cultivars, which suggests a co-evolution between the pathogen and the host $(2,19)$. In this way, the evaluation reported by Balardin and Kelly (2) showed that races 3, 38, and 102 were also particularly virulent on Andean cultivars.

Independent evaluation of each race revealed the existence of a high level of polymorphism for the resistance spectrum. However, the 32 possible spectra were not found in the present work. Similarly, using six races, 20 resistance spectra were found

Table 3. Reaction of 42 breeding lines against five races of Colletotrichum lindemuthianum isolated from Phaseolus vulgaris in northern Spain ${ }^{\mathrm{a}}$

\begin{tabular}{|c|c|c|c|c|c|}
\hline \multirow[b]{2}{*}{ Materials } & \multicolumn{5}{|c|}{ Races } \\
\hline & 3 & 6 & 38 & 102 & 19 \\
\hline Amanda, A43, A252, A321, A493, BAT93, Catrachita, SEL1308, SEL1360 & $\mathrm{R}$ & $\mathrm{R}$ & $\mathrm{R}$ & $\mathrm{R}$ & $\mathrm{R}$ \\
\hline A 483 & $\mathrm{~S}$ & $\mathrm{R}$ & $\mathrm{R}$ & $\mathrm{R}$ & $\mathrm{R}$ \\
\hline Double white & $\mathrm{R}$ & $\mathrm{S}$ & $\mathrm{R}$ & $\mathrm{R}$ & $\mathrm{R}$ \\
\hline XAN265 & $\mathrm{S}$ & $\mathrm{R}$ & $\mathrm{S}$ & $\mathrm{R}$ & $\mathrm{R}$ \\
\hline BRB85, ABA 36 & $\mathrm{R}$ & $\mathrm{S}$ & $\mathrm{S}$ & $\mathrm{R}$ & $\mathrm{R}$ \\
\hline Blanco Lara & $\mathrm{S}$ & $\mathrm{S}$ & $\mathrm{S}$ & $\mathrm{R}$ & $\mathrm{R}$ \\
\hline ARA 17, Chase, IVT7214, Red Mexican U13 & $\mathrm{R}$ & $\mathrm{R}$ & $\mathrm{R}$ & $\mathrm{S}$ & $\mathrm{R}$ \\
\hline Canadian Wonder, Pinto 114 & $\mathrm{~S}$ & $\mathrm{~S}$ & $\mathrm{~S}$ & $\mathrm{~S}$ & $\mathrm{R} / \mathrm{S}$ \\
\hline WAF9 & $\mathrm{S}$ & $\mathrm{R}$ & $\mathrm{R}$ & $\mathrm{R}$ & $\mathrm{S}$ \\
\hline UI 906, ABA71 & $\mathrm{S}$ & $\mathrm{S}$ & $\mathrm{R}$ & $\mathrm{R}$ & $\mathrm{S}$ \\
\hline A797, Sanilac & $\mathrm{S}$ & $\mathrm{I}$ & $\mathrm{R}$ & $\mathrm{R}$ & $\mathrm{S}$ \\
\hline A475 & $\mathrm{S}$ & $\mathrm{R}$ & $\mathrm{S}$ & $\mathrm{R}$ & $\mathrm{S}$ \\
\hline JaloEEP558, Canario 107 & $\mathrm{~S}$ & $\mathrm{~S}$ & $\mathrm{~S}$ & $\mathrm{R}$ & $\mathrm{S}$ \\
\hline Don Timoteo & I & $\mathrm{S}$ & I & $\mathrm{R}$ & $\mathrm{S}$ \\
\hline BRB26, ABA 58 & $\mathrm{~S}$ & $\mathrm{~S}$ & I & $\mathrm{R}$ & $\mathrm{S}$ \\
\hline PVA800A & $\mathrm{S}$ & $\mathrm{S}$ & $\mathrm{S}$ & $\mathrm{R}$ & $\mathrm{S}$ \\
\hline BRB130, Tendergreen & $\mathrm{S}$ & $\mathrm{S}$ & $\mathrm{R}$ & $\mathrm{S}$ & $\mathrm{S}$ \\
\hline Araucano INIA 85, BRB173, BRB57, BRB19, Cardinal, Blanco Español, Monroe & $\mathrm{S}$ & $\mathrm{S}$ & $\mathrm{S}$ & $\mathrm{S}$ & $\mathrm{S}$ \\
\hline
\end{tabular}

${ }^{a}$ Materials are grouped according to resistance spectrum. $\mathrm{R}=$ resistant, $\mathrm{S}=$ susceptible, $\mathrm{I}=$ intermediate reaction, and $\mathrm{R} / \mathrm{S}=$ plants resistant and susceptible.

Table 4. Observed segregation of $F 2$ progenies and $F 3$ families derived from crosses between Andecha $\left(\mathrm{R}^{3} \mathrm{~S}^{6} \mathrm{~S}^{38} \mathrm{R}^{102} \mathrm{R}^{19}\right)$ and the lines $\mathrm{A} 321$, $\mathrm{A} 252$, and $\mathrm{A} 493$ $\left(\mathrm{R}^{3} \mathrm{R}^{6} \mathrm{R}^{38} \mathrm{R}^{102} \mathrm{R}^{19}\right)$ when inoculated with race 38 of Colletotrichum lindemuthianum

\begin{tabular}{|c|c|c|c|c|c|c|c|c|c|}
\hline \multirow[b]{2}{*}{ Crosses $(\mathbf{S} \times \mathbf{R})$} & \multicolumn{2}{|c|}{ F2 segregations } & \multirow[b]{2}{*}{$\chi^{2 b}$} & \multirow[b]{2}{*}{$P$} & \multicolumn{3}{|c|}{ F3 families ${ }^{\mathrm{a}}$} & \multirow[b]{2}{*}{$\chi^{2 \mathrm{c}}$} & \multirow[b]{2}{*}{$P$} \\
\hline & $\mathbf{R}$ & $\mathbf{S}$ & & & $\mathbf{R R}$ & $\mathbf{R} / \mathbf{S}$ & $\mathbf{S}$ & & \\
\hline Andecha $\times$ A321 & 258 & 17 & 0.00 & 0.96 & 33 & 35 & 3 & 0.59 & 0.74 \\
\hline Andecha $\times$ A252 & 198 & 14 & 0.00 & 0.84 & 32 & 42 & 2 & 2.06 & 0.36 \\
\hline Andecha $\times$ A493 & 42 & 12 & 0.22 & 0.64 & 20 & 32 & 18 & 0.62 & 0.73 \\
\hline
\end{tabular}


by Cattan-Toupance et al. (3) on 128 wild common bean accessions collected in Argentina. The absence of specific combinations could suggest an association or linkage between the resistant loci involved in the reaction against specific races. An organization in clusters, including different race-specific resistance loci, has been reported by Rodríguez-Suárez et al. (15) on linkage groups B11 and B4. This organization could explain the frequency of certain combinations, requiring a recombination event in the cluster for the occurrence of different resistance spectra.

Results of our studies identified several potential sources of resistance against anthracnose race 6 and 38 prevalent in northern Spain. On the one hand, the differential cultivar set can supply some resistance sources. Inheritance of anthracnose resistance present in the differential cultivar set is relativity known, and molecular markers linked to specific loci have been described (7). The pathogenic variability found in this area suggests the use of cvs. Cornell 49-242, PI207262, AB136, or G2333 as sources of resistance. Differential cvs. TO and TU showed a resistant reaction with small symptoms for race 19 and they were not considered as potential resistance sources. The occurrence of race 9 and race Kappa (race 31) in Europe $(3,8)$ which overcome the resistance of Cornell 49-242, does not recommend the use of this material as a resistance source. Although very few races overcome the resistance of G2333, its utilization as a resistance source presents serious difficulties due to its photoperiod sensitivity (24). On the other hand, the evaluation of local accessions also can supply some resistance sources. Although accessions with resistance to the five races were not identified, some materials could be useful. Crosses between accessions with complementary resistance spectra could be used to develop lines with wider resistance spectra. Accessions with resistance to races 6 and 38 would be potential resistance sources to protect the local cultivars such as Andecha, susceptible to these races. However, the usefulness of landraces is limited by the lack of information concerning their reactions against other races or the genetic control of the anthracnose resistance present in such landraces.

Nine breeding lines were resistant to the five races. Based on the seed phenotype, the results of other evaluations against different races, and the pedigree, three lines were selected as possible resistance sources to protect cv. Andecha: lines A493, $\mathrm{A} 321$, and A252. The three lines have a different origin and probably different loci are involved in the resistance. Lines A321 and A252, with small and colored seed, were developed from Carioca/Guanajuato 31 and (BAT561/G7474)/Guanajuato 31 crosses, respectively. Lines A321 and A252 presented a wide resistance spectra in the evaluation described by Manezes and Dianese (12). Line A493 has a white seed phenotype (included in alubia market class) and it was derived from the Alubia/BAT93 cross (S. P. Singh, personal communication).

Resistance to race 38 is controlled by a single dominant gene in line A493 and by two dominant genes in lines A321 and A252. In the case of line A252, two resistant loci for race 38 previously were mapped to linkage groups B4 and B11 (15). The results obtained by Méndez de Vigo et al. (11) implied that the resistance gene in the line A493 was located on linkage group B4. In addition, a co-segregation between the resistance to race 38 and race 6 was identified in both segregating populations (Andecha/A252 and Andecha/ A493), implicating the same chromosome regions or genes in the resistance $(11,15)$.

The dominant nature of genes conferring resistance will make it easier to transfer them into cv. Andecha using backcross programs. The co-segregation for resistance to race 38 and race 6 in lines A493 and A252 makes it easier to develop resistant lines to both races. In addition, the availability of molecular markers linked to resistance loci on linkage groups B4 and B11 $(11,15)$ offers the opportunity to apply marker-assisted selection to enhance resistance in the local landrace cultivars.

\section{ACKNOWLEDGMENTS}

This research has been supported in part by grants RF99-003-C3 and RTA02-052-C2 from Ministry of Science and Technology, Spain. A. Campa and E. Pérez Vega were recipients of salary fellowships from INIA (Madrid, Spain) and Caja Rural de Gijón, respectively. We thank S. P. Singh (University of Idaho) and J. Kelly (Michigan State University) for supplying the international materials studied.

\section{LITERATURE CITED}

1. Balardin, R. S., and Kelly, J. D. 1997. Recharacterization of Colletotrichum lindemuthianum races. Annu. Rep. Bean Improv. Coop. 40:126-127.

2. Balardin, R. S., and Kelly, J. D. 1998. Interaction between Colletotrichum lindemuthianum races and gene pool diversity in Phaseolus vulgaris. J. Am. Soc. Hortic. Sci. 123:10381047.

3. Cattan-Toupance, I., Michalakis, Y., and Nema, C. 1998. Genetic structure of wild populations in their South-Andean centre of origin. Theor. Appl. Genet. 96:844-851.

4. Geffroy, V., Sévignac, M., Oliveira, J. C. F., Fouilloux, G, Skroch, P., Thoquet P., Gepts, P., Lagin, T., and Dron, M. 2000. Inheritance of partial resistance against Colletotrichum lindemuthianum in Phaseolus vulgaris and colocalization of quantitative trait loci with gene involved in specific resistance. Mol. PlantMicrobe. Interact. 13:278-296.

5. Gepts, P., and Bliss, F. A. 1988. Dissemination pathways of common bean (Phaseolus vulgaris Fabaceae) deduced from phaseolin electrophoretic variability. II. Europe and Africa. Econ. Bot. 42:86-104

6. Gepts, P., Osborn, T. C., Rashka, K., and Bliss, F. A. 1986. Phaseolin-protein variability in wild forms and landraces of the common bean (Phaseolus vulgaris): evidences for multiple centers of domestication. Econ. Bot. 40:451-468.
7. Kelly, J. D., and Vallejo, V. A. 2004. A comprehensive review of the major genes conditioning resistance to anthracnose in common bean. Hortscience 39:1196-1207.

8. Krüger, D. J., Hoffmann, G. M., and Hubbeling, N. 1977. The kappa race of Colletotrichum lindemuthianum and sources of resistance to anthracnose in Phaseolus beans. Euphytica 26:23-25

9. Mahuku, G. S., Jara, C., Cajiaco, C., and Beebe, S. 2002. Sources of resistance to Colletotrichum lindemuthianum in the secondary gene pool of Phaseolus vulgaris L. and in crosses of primary and secondary gene pools. Plant Dis. 86:1383-1387.

10. Mahuku, G. S., and Riascos, J. J. 2004. Virulence and molecular diversity within Colletotrichum lindemuthianum isolates from Andean and Mesoamerican bean varieties and regions. Eur. J. Plant Pathol. 110:253-263.

11. Méndez de Vigo, B., Rodríguez-Suárez, C., Pañeda, A., Ferreira J. J., and Giraldez, R. 2005. Molecular markers and allelic relationships of anthracnose resistance gene cluster B4 in common bean. Euphytica 141:237-245.

12. Menezes, J. R., and Dianese, J. C. 1988. Race characterization of Brazilian isolates of Colletotrichum lindemuthianum and detection of resistance to anthracnose in Phaseolus vulgaris. Phytopathology 78:650-655.

13. Pastor-Corrales, M. A. 1991. Estandarización de variedades diferenciales y designación de razas de Colletotrichum lindemuthianum. (Abstr.). Phytopathology 81:694.

14. Pastor-Corrales, M. A., Otoya, M. M., Molina, A., and Singh, S. P. 1995. Resistance to Colletotrichum lindemuthianum isolates from Middle America and Andean South America in different common bean races. Plant Dis. 79:63-67.

15. Rodríguez-Suárez, C., Méndez-Vigo, B. Pañeda, A., Ferreira, J. J., and Giraldez, R. 2007. A genetic linkage map of Phaseolus vulgaris L. and localization of genes for specific resistance to six races of anthracnose (Colletotrichum lindemuthianum). Theor. Appl. Genet. 114:713-722.

16. Santalla, M., De Ron, A., and Voyset, O. 2001 European bean market classes. Pages 79-94 in: Catalogue of Bean Genetic Resources. M Amurrio, M. Santalla, and A. De Ron, eds PHASELIEU FAIR PL97-3463.

17. Santalla, M., Rodiño, P., and De Ron, A. 2002. Allozyme evidences supporting southwestern Europe as a secondary center of genetic diversity for the common bean. Theor. Appl. Genet. 104:934-944.

18. Schwartz, H. F., Pastor Corrales, M. A., and Singh S. P. 1982. New sources of resistance to anthracnose an angular leaf spot of beans (Phaseolus vulgaris L). Euphytica 31:741-754.

19. Sicard, D., Michalakis, Y., Dron, M., and Neema, C. 1997. Genetics diversity and pathogenic variation of Colletotrichum lindemuthianum in three centers of diversity of its host, Phaseolus vulgaris. Phytopathology 87:807813.

20. Singh, S. P., Gepts, P., and Debouck D. 1991. Races of common bean (Phaseolus vulgaris Fabaceae). Econ. Bot. 45:379-396.

21. Tohme, J., González, O. D., Beebe, S., and Duque, M. 1996. AFLP analysis of gene pools of a wild bean core collection. Crop Sci. 36:1375-1384.

22. Tu, J. C. 1988. Control of bean anthracnose caused by the delta and lambda races of Colletotrichum lindemuthianum in Canada. Plant Dis. 72:5-8.

23. van Schoonhoven, A, and Pastor Corrales, M. 1987. Standard System for the Evaluation of Bean Germplasm. CIAT, Cali, Colombia.

24. Young R. A., Melotto, M., Nodari R. O., and Kelly, J. D. 1998. Marker-assisted dissection of the oligogenic anthracnose resistance in the common bean. Theor. Appl. Genet. 96:87-94. 